\title{
GAMBARAN ELEKTROENSEFALOGRAFI PADA MENINGITIS TUBERKULOSIS YANG MENGALAMI BANGKITAN SIMTOMATIK AKUT
}

\author{
ELECTROENCEPHALOGRAPHY FINDINGS IN TUBERCULOUS MENINGITIS WITH ACUTE \\ SYMPTOMATIC SEIZURES
}

Suryani Gunadharma, * Sobaryati, * Hendra Irawan*

\section{ABSTRACT}

Introductions: Electroencephalography (EEG) can detect abnormal cortical excitability, causing epileptic seizure. Acute symptomatic seizure can caused by tuberculous meningitis (TBM) which can further develope to symptomatic epilepsy. We are interested to study the characteristic of EEG pattern in TBM patients with acute symptomatic seizure.

Aims: To investigate characteristic of EEG pattern in TBM with acute symptomatic seizure.

Methods: This was an descriptive observational study, from secondary medical record datas and EEG reports from acute symptomatic seizure patients caused by TBM during admited in Hasan Sadikin General Hospital, in 11 years periode from January 2006 to December 2016.

Results: Fourty four subjects were enrolled in this study. The EEG pattern showed focal slowing 70.5\%, 61.4\% had unilateral focal slowing, and $9.1 \%$ had bilateral focal slowing. Focal epileptogenic waves were only found in $25.0 \%$ and $4.5 \%$ showed triphasic waves.

Discussion: Electroencephalogram in acute symptomatic seizure due to TBM showed abnormality in $100 \%$ subjects. Almost all EEG abnormality concordances with neuro imaging findings.

Keyword: Acute symptomatic seizure, EEG, tuberculous meningitis

\section{ABSTRAK}

Pendahuluan: Pemeriksaan elektroensefalografi (EEG) menggambarkan secara fisiologis eksitabilitas kortikal yang abnormal yang mendasari terjadinya bangkitan epileptik. Bangkitan simtomatik akut (BSA) dapat disebabkan oleh meningitis tuberkulosis (MTB) dan dapat berkembang menjadi epilepsi simtomatik. Peneliti tertarik untuk melihat gambaran EEG apa saja yang mungkin ditemukan pada BSA yang disebabkan MTB.

Tujuan: Mengetahui karakteristik gambaran EEG pasien MTB yang mengalami BSA.

Metode: Penelitian deskriptif observasional, studi potong lintang yang bersifat retrospektif menggunakan data sekunder rekam medis dan hasil pemeriksaan EEG pada pasien MTB dewasa yang mengalami BSA di Rumah sakit Dr. Hasan Sadikin Bandung selama 11 tahun periode Januari 2006 sampai dengan Desember 2016.

Hasil: Ditemukan 44 subjek yang memenuhi syarat penelitian. Gambaran mayoritas berupa perlambatan fokal $70,5 \%$, terdiri dari perlambatan fokal unilateral $61,4 \%$ dan perlambatan fokal bilateral $9,1 \%$. Gelombang epileptogenik fokal hanya didapatkan pada $25,0 \%$ dan $4,5 \%$ lainnya menunjukkan gelombang trifasik.

Diskusi: Gambaran EEG pada MTB yang mengalami BSA 100\% menunjukkan abnormalitas. Hampir semua gambaran EEG sesuai dengan lokasi lesi pada pencitraan otak.

Kata kunci: Bangkitan simtomatik akut, EEG, meningitis tuberkulosis

*Departemen Neurologi FK Universitas Padjadjaran/RSUP Dr.Hasan Sadikin, Bandung. Korespondensi: hen_dr_4@ yahoo.com.

\section{PENDAHULUAN}

Meningitis tuberkulosis (MTB) merupakan manifestasi infeksi Mycobacterium tuberculosis (M. tuberculosis) yang melibatkan sistem saraf pusat (SSP) yang sering ditemukan di daerah endemik tuberkulosis (TB). ${ }^{1,2}$ Secara klinis, MTB ditandai dengan panas badan, nyeri kepala, penurunan kesadaran, defisit neurologis fokal dan bangkitan epileptik. ${ }^{2,3}$ Berdasarkan data World Health Organization (WHO) tahun 2014, prevalensi MTB tertinggi terdapat di Afrika dengan 343/100.000 populasi, Asia Tenggara menduduki peringkat kedua dengan 181/100.000 populasi. ${ }^{4}$

Meningitis tuberkulosis dapat menyebabkan terjadinya bangkitan simtomatik akut (BSA) pada saat infeksi berlangsung atau menjadi epilepsi sebagai gejala sisa MTB. Terjadinya BSA pada MTB ini dapat meningkatkan risiko untuk terjadinya epilepsi di kemudian hari., ${ }^{3,5}$

Bangkitan epileptik dapat disebut BSA jika terjadi dalam 7 hari pada penyakit serebrovaskular, cedera kepala, termasuk operasi intrakranial, kelainan 
metabolik, toksik dan infeksi SSP salah satunya adalah MTB. Pada MTB, bangkitan simtomatik akut dapat pula berlangsung lebih dari 7 hari, mulai dari onset MTB atau selama gejala klinis maupun laboratorium masih menunjang diagnosis MTB, bahkan selama mendapat terapi obat anti tuberkulosis (OAT). ${ }^{3,6}$

Bangkitan simtomatik akut dapat terjadi pada $10-20 \%$ pasien MTB dalam berbagai stadium dari MTB. 2,7,8 Kejadian BSA pada MTB akan meningkatkan disabilitas, defisit neurologis dan juga mortalitas, sering juga memerlukan pemberian obat anti epilepsi (OAE) jangka panjang., ${ }^{2,3}$

\section{Pemeriksaan elektroensefalografi (EEG)} menunjukkan secara fisiologis eksitabilitas kortikal yang abnormal yang mendasari terjadinya bangkitan epileptik. ${ }^{910}$ Pemeriksaan EEG berperan dalam menegakkan diagnosis epilepsi sehingga dapat membuat rencana penatalaksaan selanjutnya terhadap pasien MTB yang mengalami BSA. ${ }^{9}$ Pada BSA yang ditemukan fokus epileptogenik pada gambaran EEG perlu diberikan OAE jangka panjang. ${ }^{11}$

Etiologi terjadinya bangkitan epileptik pada pasien MTB disebabkan multifaktorial, antara lain: tekanan tinggi intrakranial (TTIK), edema otak, hidrosefalus, iritasi meningen, terdapatnya tuberkuloma, infark serebri dan ensefalopati akibat perubahan yang terjadi selama proses penyakit MTB. ${ }^{2,3,8-10,12}$ Masing-masing atau kombinasi dari etiologi-etiologi tersebut dapat menyebabkan perubahan gambaran EEG. ${ }^{9}$

Pada hidrosefalus dapat ditemukan perlambatan fokal atau bilateral dengan sebagian besar mempunyai irama dasar yang normal atau dengan irama dasar lambat sedang sampai berat, spindle tidur asimetri dengan atau tanpa disertai fokus epileptogenik. Pada pasien yang terpasang shunt ventrikular dapat ditemukan perlambatan fokal intermiten dengan irama delta maupun theta. ${ }^{13}$ Gambaran EEG pada iritasi meningen daerah basal dapat normal atau menunjukkan perubahan ringan yang tidak spesifik berupa perlambatan intermiten menyeluruh. Bila terdapat keterlibatan korteks serebri dan meningen dapat menunjukkan gambaran EEG berupa perlambatan baik fokal atau menyeluruh. Beratnya perlambatan tergantung pada sejauh mana keterlibatan korteks serebri, progresifitas MTB, tingkat kesadaran, gangguan keseimbangan elektrolit dan obat-obatan. ${ }^{3,13}$ Pada infark serebri atau tuberkuloma dapat ditemukan amplitudo asimetri interhemisfer, irama dasar lambat, gelombang paku ombak multipel dan perlambatan fokal. Pada TTIK dapat ditemukan irama dasar lambat, aktifitas delta di daerah frontal yang intermiten ritmik (FIRDA) dan perlambatan intermiten menyeluruh. ${ }^{3,11,13}$

Pada metabolik ensefalopati dapat ditemukan gelombang trifasik, irama dasar lambat, perlambatan kontinu menyeluruh dan aktifitas gelombang delta intermiten ritmik (IRDA) yang berkaitan dengan perubahan histopatologi dan kerusakan substansia grisea yang melibatkan kedua daerah kortikal dan subkortikal. ${ }^{6,13}$ Gelombang trifasik biasanya ditemukan pada kondisi metabolik ensefalopati, khususnya pada keadaan ensefalopati hepatikum, dapat juga ditemukan pada ensefalopati uremikum, hiponatremia berat $(<120 \mathrm{mg} / \mathrm{dL})$, hiperkalsemia (kalsium $>13 \mathrm{mg} / \mathrm{dL}$ ) dan sepsis. ${ }^{6,14}$ Gelombang trifasik dapat ditemukan pada 6-12\% kondisi sepsis. ${ }^{15}$

Perlambatan menyeluruh dan gelombang paku ombak multipel paling sering ditemukan pada bangkitan epileptik umum tonik klonik dan tonik dalam minggu pertama perawatan MTB yang tidak selalu berhubungan dengan lesi intrakranial (seperti tuberkuloma dan infark). Pada 12\% bangkitan epileptik umum tonik klonik tidak ada penyebab yang dapat ditemukan dan pada pasien-pasien ini tidak terjadi bangkitan epileptik berulang setelah perawatan MTB. ${ }^{11}$ Terdapatnya gelombang epileptogenik pada gambaran EEG diawal diagnosis MTB dikaitkan dengan prognosis yang buruk..$^{3,9,13}$ Perlambatan fokal yang kontinu dengan frekuensi delta $20 \%$ juga mempunyai hubungan dengan bangkitan epileptik. ${ }^{16}$

Selain evaluasi klinis, pemeriksaan seperti EEG dan pencitraan otak mungkin diperlukan untuk menyingkirkan lesi di otak seperti tuberkuloma dan infark serebri yang dapat mengakibatkan bangkitan epileptik berulang. ${ }^{3,17}$

\section{TUJUAN}

Untuk mengetahui karakteristik gambaran EEG pasien MTB yang mengalami BSA. 


\section{METODE}

Penelitian ini mempunyai rancangan deskriptif observasional yang dilakukan secara potong lintang pada data sekunder berupa rekam medis pasien MTB yang mengalami BSA tanpa ada riwayat epilepsi sebelumnya. Penelitian bersifat retrospektif dengan periode 11 tahun sejak Januari 2006 sampai dengan Desember 2016 di Rumah Sakit Dr. Hasan Sadikin Bandung.

Diagnosis MTB ditegakkan berdasarkan kriteria Marais minimal 6 tanpa memasukkan kriteria
C pencitraan otak (Tabel 1). ${ }^{18}$ Bangkitan simtomatik akut diketahui berdasarkan anamnesis yang terlampir di rekam medis. Penyebab BSA dan hasil pemeriksaan EEG didokumentasikan. Interpretasi hasil EEG dilakukan oleh seorang dokter spesialis saraf konsultan neurofisiologi (elektroensefalografer).

\section{HASIL}

Dalam penelitian ini didapatkan total 1114 pasien MTB dengan skoring Marais $\geq 6$ semuanya dilengkapi hasil pemeriksaan lumbal pungsi. Seratus lima puluh satu pasien $(13,6 \%)$ mengalami BSA tetapi

Tabel 1. Marais Skor

\begin{tabular}{lc}
\hline Kriteria & Skor Diagnostik \\
\hline A. Kriteria Klinis & Skor Maksimum =6 \\
Lama gejala $>5$ hari & 4 \\
Gejala sistemik yang menunjang diagnosis TB (1 atau lebih): penurunan berat badan/ & 2 \\
gagal tumbuh (pada anak), keringat malam, batuk lama (>2 minggu) & \\
Riwayat kontak dengan TB paru (dalam 1 tahun terakhir) & 2 \\
Defisit neurologis fokal (tidak termasuk kelumpuhan saraf kranial) & 1 \\
Kelumpuhan saraf cranial & 1 \\
Penurunan kesadaran & 1 \\
B. Kriteria CSS & Skor Maksimum=4 \\
Warna jernih/xantochrom & 1 \\
Jumlah sel 10-500 & 1 \\
Predominasi limfosit (>50\%) & 1 \\
Protein >1gr/L & 1 \\
Rasio glukosa CSS : plasma $<50 \%$ & 1 \\
C. Kriteria CT scan/MRI & Skor Maksimum=6 \\
Hidrosefalus & 1 \\
Penyengatan basal meningeal & 2 \\
Tuberkuloma & 2 \\
Infark & 1 \\
Hiperdensitas basal pra-kontras & 2 \\
D. Tanda TB di Tempat Lain & Skor Maksimum=4 \\
Gambaran rontgen thorax: TB paru=2, TB milier=4 & 2 atau 4 \\
Bukti CT/MRI/USG yang menunjukkan adanya TB diluar SSP & 2 \\
Didapatkan BTA baik dari pewarnaan langsung atau kultur dari sampel lain selain & 4 \\
CSS (sputum,kelenjar getah bening,bilas lambung,urine,darah) & \\
Hasil positif dari NAAT M.tuberculosis komersial dari bahan pemeriksaan selain CSS & 4 \\
\hline
\end{tabular}

TB: tuberkulosis; CSS: cairan serebro spinal; CT: computed tomography; MRI: magnetic resonance imaging; USG: ultrasonography; SSP: sistem saraf pusat; BTA: basil tahan asam; NAAT: nucleic acid amplification test. Definite, jika memenuhi kriteria A atau B: A. Kriteria gejala klinis ditambah satu atau lebih dari berikut: BTA ditemukan dalam CSS, kultur M. tuberculosis dari CSS positif atau pemeriksaan NAAT dari CSS positif. B. BTA positif secara histologis konsisten dengan gejala, tanda, dan perubahan CSS yang sugestif untuk TB di otak atau medula spinalis atau meningitis yang visibel pada otopsi: Probable jika memenuhi kriteria gejala klinis ditambah skor diagnostik total $\geq 10$, serta telah diakukan eksklusi diagnosis banding. Setidaknya 2 poin didapat dari kriteria CSS; Possible jika memenuhi kriteria gejala klinis ditambah skor diagnostik total 6-9 serta telah diakukan eksklusi diagnosis banding. Kriteria ini tidak dapat ditegakkan atau disingkirkan tanpa pungsi lumbal atau pencitraan otak. 
hanya 44 pasien yang memenuhi syarat penelitian (eligible). Gambaran karakteristik subjek penelitian dapat dilihat pada Tabel 2. Bangkitan simtomatik akut terbanyak terjadi pada stadium 3 MTB 33 subjek (75,0\%). Gangguan keseimbangan elektrolit hanya didapatkan hipokalsemia $<5 \mathrm{mg} / \mathrm{dL}$ pada 22 subjek (75,9\%), tetapi tidak ada satu subjek pun yang mengalami hipokalsemia murni. Pada subjek penelitian yang dilakukan pencitraan otak didapatkan hidrosefalus komunikan sebagai kelainan tersering diikuti infark serebri, penyangatan meningen dan tuberkuloma, dimana satu subjek dapat memiliki

Tabel 2. Karakteristik Subjek Penelitian $(n=44)$

\begin{tabular}{|c|c|}
\hline Variabel & n $(\%)$ \\
\hline \multicolumn{2}{|l|}{ Usia (tahun) } \\
\hline - $\operatorname{Rerata} \pm S D$ & $30,6 \pm 11,9$ \\
\hline - Median (Min-maks) & $28,5(16,0-76,0)$ \\
\hline \multicolumn{2}{|l|}{ Jenis Kelamin } \\
\hline - Laki-laki & $24(54,5)$ \\
\hline - Perempuan & $20(45,5)$ \\
\hline \multicolumn{2}{|l|}{ Klinis } \\
\hline - Penurunan kesadaran & $31(70,5)$ \\
\hline - Bangkitan fokal & $27(61,4)$ \\
\hline - Bangkitan umum & $17(38,6)$ \\
\hline \multirow{2}{*}{\multicolumn{2}{|c|}{$\begin{array}{l}\text { Etiologi Bangkitan Simptomatik Akut } \\
\text { - } \quad \text { Stadium penyakit MTB }\end{array}$}} \\
\hline & \\
\hline - $\quad$ Stadium 1 & $0(0,0)$ \\
\hline - $\quad$ Stadium 2 & $11(25,0)$ \\
\hline - Stadium 3 & $33(75,0)$ \\
\hline \multicolumn{2}{|l|}{ - Lesi intrakranial } \\
\hline - Pencitraan otak & $32(72,7)$ \\
\hline - Infark & $16(50,0)$ \\
\hline - Hidrosefalus komunikans & $19(59,4)$ \\
\hline - Penyangatan meningen & $16(50,0)$ \\
\hline - Tuberkuloma & $4(12,5)$ \\
\hline \multicolumn{2}{|l|}{ - Gangguan metabolik } \\
\hline - Hiponatremia $<115 \mathrm{mg} / \mathrm{dL}$ & $0(0,0)$ \\
\hline - Hiperkalsemia $<13,5 \mathrm{mg} / \mathrm{dL}$ & $0(0,0)$ \\
\hline - Hipomagnesemia $<0,8 \mathrm{mg} / \mathrm{dL}$ & $0(0,0)$ \\
\hline - Pemeriksaan kalsium & $29(65,9)$ \\
\hline - Hipokalsemia <5mg/dL & $22(75,9)$ \\
\hline - Gangguan fungsi hati & $2(4,5)$ \\
\hline - Gangguan fungsi ginjal & $1(2,3)$ \\
\hline - Sepsis & $1(2,3)$ \\
\hline
\end{tabular}

lebih dari satu kelainan pada pencitraan otak.

Gambaran EEG abnormal ditemukan pada semua subjek. Mayoritas berupa perlambatan fokal pada 31 subjek $(70,5 \%)$ terdiri dari perlambatan intermiten fokal unilateral pada 25 subjek $(56,8 \%)$, perlambatan intermiten fokal bilateral pada 4 subjek $(9,1 \%)$ dan perlambatan kontinu fokal pada 2 subjek (4,5\%). Gelombang trifasik ditemukan pada 2 subjek $(4,5 \%)$ dan gelombang epileptogenik fokal hanya ditemukan pada 11 subjek (25,0\%) (Tabel 3). Semua gelombang epileptogenik fokal hanya ditemukan pada stadium 3 MTB dan $83,3 \%$ sesuai dengan lokasi lesi intrakranial (Tabel 4).

Tabel 3. Karakteristik Kelainan EEG $(n=44)$

\begin{tabular}{lc}
\hline Klasifikasi EEG & $\mathbf{n}(\mathbf{\%})$ \\
\hline Normal & $0(0,0)$ \\
Abnormal & $44(100,0)$ \\
- Perlambatan intermiten fokal unilateral & $25(56,8)$ \\
- Perlambatan intermiten fokal bilateral & $4(9,1)$ \\
- Gelombang epileptogenik fokal & $11(25,0)$ \\
- Perlambatan kontinu fokal & $2(4,5)$ \\
- Gelombang trifasik & $2(4,5)$ \\
\hline
\end{tabular}

EEG: electroencephalography.

Tabel 4. Gambaran EEG Pada Stadium Penyakit MTB $(n=44)$

\begin{tabular}{lcc}
\hline \multirow{1}{*}{ Gambaran EEG } & \multicolumn{2}{c}{ Stadium MTB } \\
\cline { 2 - 3 } & $\begin{array}{c}\text { Stadium } 2 \\
\mathbf{( n = 1 1 )} \\
\mathbf{n}(\mathbf{\%})\end{array}$ & $\begin{array}{c}\text { Stadium 3 } \\
\mathbf{( n = 3 3 )} \\
\mathbf{n}(\mathbf{\%})\end{array}$ \\
\hline $\begin{array}{l}\text { Perlambatan Intermiten Fokal } \\
\text { Unilateral }\end{array}$ & $9(81,8)$ & $16(48,5)$ \\
$\begin{array}{l}\text { Perlambatan Intermiten Fokal } \\
\text { Bilateral }\end{array}$ & $0(0,0)$ & $4(12,1)$ \\
Perlambatan Kontinu Fokal & $0(0,0)$ & $2(6,1)$ \\
Gelombang Epileptogenik Fokal & $0(0,0)$ & $11(33,3)$ \\
Gelombang Trifasik & $2(18,2)$ & $0(0,0)$ \\
\hline
\end{tabular}

EEG: electroencephalography; MTB: meningitis tuberkulosis.

Dari 31 subjek dengan gambaran EEG perlambatan fokal, hanya 25 subjek yang disertai pencitraan otak, terdiri dari 4 subjek $(100,0 \%)$ ditemukan tuberkuloma, 11 subjek $(68,8 \%)$ dengan infark serebri, 14 subjek (74,7\%) dengan hidrosefalus komunikan. Gambaran EEG sesuai dengan lokasi lesi pada pencitraan otak, kecuali pada 2 subjek dengan pencitraan otak normal. Dari 11 subjek dengan 
gelombang epileptogenik, hanya 6 yang disertai pencitraan otak, terdiri dari 4 subjek $(25,0 \%)$ dengan infark serebri, $1(5,3 \%)$ subjek terpasang shunt ventrikular dan 1 subjek (5,3\%) dengan hidrosefalus komunikan. Gambaran EEG sesuai lokasi lesi pada pencitraan otak. Dari 2 subjek dengan gelombang trifasik, 1 subjek disertai pencitraan otak dan meninggal karena syok sepsis (Tabel 5 dan 6). Satu subjek lainnya disertai kesadaran delirium tanpa penyebab metabolik yang jelas dan tanpa pencitraan otak. karena pencitraan otak dilakukan tanpa kontras.

Perlambatan fokal maupun bilateral ditemukan

pada hidrosefalus komunikan. Gelombang epileptogenik lainnya ditemukan pada hidrosefalus komunikan dan pada subjek dengan shunt ventrikular. Sesuai dengan penelitian sebelumnya, pada hidrosefalus dapat ditemukan perlambatan fokal atau bilateral dengan sebagian besar mempunyai irama dasar yang normal atau irama dasar lambat, spindle tidur asimetri dengan atau tanpa disertai fokus epileptogenik. ${ }^{13}$

Tabel 5. Gambaran EEG berdasarkan Pencitraan Otak $(n=44)$

\begin{tabular}{lcccc}
\hline & \multicolumn{3}{c}{ Pencitraan Otak } \\
\cline { 2 - 5 } \multicolumn{1}{c}{ EEG } & $\begin{array}{c}\text { Infark } \\
(\mathbf{n = 1 6 )}\end{array}$ & $\begin{array}{c}\text { Hidrosefalus } \\
\text { Komunikan } \\
(\mathbf{n = 1 9 )}\end{array}$ & $\begin{array}{c}\text { Penyangatan Meningen } \\
(\mathbf{n = 1 6 )}\end{array}$ & $\begin{array}{c}\text { Tuberkuloma } \\
(\mathbf{n}=\mathbf{4})\end{array}$ \\
& $\mathbf{n}(\mathbf{\%})$ & $\mathbf{n}(\mathbf{\%})$ & $\mathbf{n}(\mathbf{\%})$ & $\mathbf{n}(\mathbf{\%})$ \\
\hline Perlambatan Intermiten Fokal Unilateral & $9(56,3)$ & $12(63,2)$ & $10(62,5)$ & $4(100,0)$ \\
Perlambatan Intermiten Fokal Bilateral & $0(0,0)$ & $2(10,5)$ & $2(12,5)$ & $0(0,0)$ \\
Perlambatan Kontinu Fokal & $2(12,5)$ & $0(0,0)$ & $1(6,3)$ & $0(0,0)$ \\
Gelombang Epileptogenik Fokal & $4(25,0)$ & $4(21,1)$ & $2(12,5)$ & $0(0,0)$ \\
Gelombang Trifasik & $1(6,3)$ & $1(5,3)$ & $1(6,3)$ & $0(0,0)$ \\
\hline
\end{tabular}

Setiap subjek dapat memiliki lebih dari 1 hasil pencitraan otak, 1 subjek gelombang trifasik disertai dengan sepsis. EEG: Electroencephalography.

\section{PEMBAHASAN}

Untuk penelitian ini gambaran EEG yang diambil untuk penghitungan statistik hanya satu gambaran abnormalitas terberat. Gelombang epileptogenik fokal ditemukan pada 11 subjek $(25,0 \%)$ dan semuanya pada stadium 3 MTB. Penelitian sebelumnya yang dilakukan pada seluruh pasien MTB tanpa menilai ada atau tidak BSA, gelombang epileptogenik ditemukan pada 3,7-12,5\% subjek. ${ }^{13}$ Pada penelitian ini subjek yang dilakukan pemeriksaan EEG adalah pasien MTB yang mengalami BSA. Gambaran EEG abnormal dan gelombang epileptogenik sering ditemukan pada MTB stadium 3., 13

Perlambatan fokal ditemukan pada infark serebri dan tuberkuloma. Pada infark juga ditemukan gelombang epileptogenik. Sesuai dengan penelitian sebelumnya, pada infark serebri dan tuberkuloma dapat ditemukan gelombang paku ombak multipel dan perlambatan fokal. ${ }^{11,13}$ Pada 2 subjek yang tidak sesuai dengan pencitraan otak, hal ini mungkin
Gelombang trifasik yang ditemukan pada penelitian ini sesuai dengan penelitian sebelumnya. Gelombang trifasik dapat ditemukan pada kondisi sepsis dan penurunan kesadaran ringan. ${ }^{6,13-15,19}$

Penelitian ini mengalami kesulitan untuk pemenuhan jumlah sampel yang diinginkan karena prevalensi kejadian BSA pada MTB tidak besar dan terkendala masalah data sekunder rekam medis yang tidak lengkap. Keterbatasan untuk menentukan etiologi yang lebih menonjol yang menyebabkan perubahan gambaran EEG berdasarkan etiologi yang multifaktorial, disebabkan jumlah sampel yang tidak cukup. Perlu untuk dilakukan penelitian selanjutnya dengan jumlah sampel yang lebih besar dan data yang lebih lengkap.

\section{KESIMPULAN}

Semua gambaran EEG pada MTB yang mengalami BSA menunjukkan abnormalitas. Hampir semua kelainan EEG fokal ditemukan sesuai lokasi lesi pada pencitraan otak. 
Tabel 6. Gambaran EEG berdasarkan Etiologi Multifaktorial $(n=44)$

\begin{tabular}{|c|c|c|c|c|}
\hline Gelombang EEG & $\begin{array}{l}\text { Stadium } \\
\text { MTB }\end{array}$ & Pencitraan Otak & $\begin{array}{l}\text { Gangguan } \\
\text { Metabolik }\end{array}$ & n (\%) \\
\hline \multirow[t]{18}{*}{$\begin{array}{l}\text { Perlambatan Intermiten } \\
\text { Fokal Unilateral }\end{array}$} & 2 & Pencitraan otak non kontras normal & & $1(2,3)$ \\
\hline & 2 & Penyangatan meningen + infark & & $2(4,5)$ \\
\hline & 2 & Hidrosefalus komunikans + tuberkuloma & & $1(2,3)$ \\
\hline & 2 & Hidrosefalus komunikans & Hipokalsemia & $2(4,5)$ \\
\hline & 2 & Hidrosefalus komunikans + infark & Hipokalsemia & $2(4,5)$ \\
\hline & 2 & Penyangatan meningen + infark & Hipokalsemia & $1(2,3)$ \\
\hline & 3 & Tanpa pencitraan otak & & $2(4,5)$ \\
\hline & 3 & Penyangatan meningen + infark & & $1(2,3)$ \\
\hline & 3 & Hidrosefalus komunikans & & $2(4,5)$ \\
\hline & 3 & $\begin{array}{l}\text { Hidrosefalus komunikans }+ \text { penyangatan } \\
\text { meningen }+ \text { tuberkuloma }\end{array}$ & & $1(2,3)$ \\
\hline & 3 & Hidrosefalus komunikans + penyangatan meningen & & $1(2,3)$ \\
\hline & 3 & Penyangatan meningen + tuberkuloma & & $1(2,3)$ \\
\hline & 3 & Penyangatan meningen & & $1(2,3)$ \\
\hline & 3 & Infark + tuberkuloma & & $1(2,3)$ \\
\hline & 3 & Tanpa pencitraan otak & Hipokalsemia & $3(6,8)$ \\
\hline & 3 & $\begin{array}{l}\text { Hidrosefalus komunikans }+ \text { penyangatan } \\
\text { meningen }+ \text { infark }\end{array}$ & Hipokalsemia & $1(2,3)$ \\
\hline & 3 & $\begin{array}{l}\text { Hidrosefalus komunikans }+ \text { penyangatan } \\
\text { meningen }\end{array}$ & Hipokalsemia & $1(2,3)$ \\
\hline & 3 & Hidrosefalus komunikans + infark & Hipokalsemia & $1(2,3)$ \\
\hline \multirow[t]{4}{*}{$\begin{array}{l}\text { Perlambatan Intermiten } \\
\text { Fokal Bilateral }\end{array}$} & 3 & Tanpa pencitraan otak & & $1(2,3)$ \\
\hline & 3 & Pencitraan otak non kontras normal & & $1(2,3)$ \\
\hline & 3 & Hidrosefalus komunikan + penyangatan meningen & & $1(2,3)$ \\
\hline & 3 & Hidrosefalus komunikan + penyangatan meningen & Hipokalsemia & $1(2,3)$ \\
\hline \multirow[t]{2}{*}{ Perlambatan Kontinu Fokal } & 3 & Penyangatan meningen + infark & Hipokalsemia & $1(2,3)$ \\
\hline & 3 & Tanpa pencitraan otak & Hipokalsemia & $1(2,3)$ \\
\hline \multirow[t]{8}{*}{$\begin{array}{l}\text { Gelombang Epileptogenik } \\
\text { Fokal }\end{array}$} & 3 & Tanpa pencitraan otak & & $2(4,5)$ \\
\hline & 3 & Hidrosefalus komunikan & & $1(2,3)$ \\
\hline & 3 & Tanpa pencitraan otak & Hipokalsemia & $3(6,8)$ \\
\hline & 3 & $\begin{array}{l}\text { Hidrosefalus komunikan }+ \text { penyangatan meningen } \\
+ \text { infark }\end{array}$ & Hipokalsemia & $1(2,3)$ \\
\hline & 3 & Hidrosefalus komunikan + infark & Hipokalsemia & $1(2,3)$ \\
\hline & 3 & Hidrosefalus komunikan (terpasang shunt ventrikular) & Hipokalsemia & $1(2,3)$ \\
\hline & 3 & Penyangatan meningen + infark & Hipokalsemia & $1(2,3)$ \\
\hline & 3 & Infark & Hipokalsemia & $1(2,3)$ \\
\hline \multirow[t]{2}{*}{ Gelombang Trifasik } & 2 & Tanpa pencitraan otak & & $1(2,3)$ \\
\hline & 2 & $\begin{array}{l}\text { Hidrosefalus Komunikan }+ \text { penyangatan meningen } \\
+ \text { infark }\end{array}$ & Hipokalsemia & $1(2,2)$ \\
\hline
\end{tabular}

EEG: electroencephalography; MTB: meningitis tuberkulosis. 


\section{UCAPAN TERIMA KASIH}

Penelitian ini mendapatkan dana dari hibah internal Fakultas Kedokteran Universitas Padjadjaran tahun 2016.

\section{DAFTAR PUSTAKA}

1. Pasco PM. Diagnostic features of tuberculous meningitis: a cross-sectional study. BMC Research Notes. 2012;5(9):1-6.

2. Brigo F, Ausserer H, Zuccoli G, Tezzon F, Nardone R. Seizure heralding tuberculous meningitis. Epileptic Disord. 2012;14(3);329-33.

3. Abdulaziz ATA, Li.J., Zhou D, The prevalence, characteristics and outcome of seizure in tuberculous meningitis. Acta Epileptologica. 2020.

4. Kongbunkiat K, Deesomsak M, Sawanyawisuth $\mathrm{K}$, Chotmongkol V, Tiamkao S. Clinical factors predictive of fungtional outcomes in tuberculous meningitis. Southeast Asian J Trop Med Public Health. 2014;45;1114-8.

5. Park S, Hong JY, Lee MK, Kim EY. Hippocampal sclerosis and encephalomalacia as prognostic factors of tuberculous meningitis-related and herpes simplex encephalitis-related epilepsy. Seizure. 2011;20(7):570-4

6. Beghi E, Carpio A, Forsgren L, Hesdorffer DC, Malmgren K, Sander JW, dkk. Recommendation for a Definition of Acute Symptomatic Seizure. Epilepsia. 2010;51(4);671-5.

7. Danciu FA, Bistriceanu CE. Cerebral tuberculosis and secondary epilepsy-Interactions between antiepileptic and antituberculous treatment. Arch Clin Cases. 2015;2(1);24-9.

8. Misra UK, Kalita J. Management of Provoked Seizure. Ann Indian Acad Neurol. 2011;14(1);2-8.

9. Gunawan PI, Saharso D. Seizure increases electroencephalographic abnormalities in children with tuberculous meningitis. Universa Medicina. 2015;34(3);161-7.
10. Song X, Wen L, Li M, Yu X, Wang L, Li K. Newonset seizures in adults with tuberculous meningitis during long-term follow-up: Characteristics, functional outcomes and risk factors. Int J Infect Dis. 2020;. 258-63

11. Patwari AK, Aneja S, Ravi RNM, Singhal PK, Arora SK. Convulsions in tuberculous meningitis. J Trop Pediatr. 1996;42;91-7.

12. Misra UK, K.M., Kalita J. Seizures in tuberculous meningitis. Epilepsy Res 2018; 90-5.

13. Kalita J, Misra UK. EEG changes in tuberculous meningitis: a clinicoradiological correlation. Electroenceph clin Neurophysiol. 1998;107;39-43.

14. Chaudhry N, Duggal AK. Sepsis associated encephalopathy. Hindawi Publishing Corporation. 2014;1-17.

15. Tsuruta R, Oda Y. A clinical perspective of sepsisassociated delirium. J Intensive Care. 2016;4:1-7.

16. Pedley TA, Mendiratta A, Walczak TS. Seizures and Epilepsy. Dalam: Ebersole JS, Pedley TA, Editors. Current practice of clinical electroencephalography. Lippincott Williams \& Wilkins: Philadelphia. 2003; 10:506-87.

17. Patwari AK, Aneja S, Chandra D, Singhal PK. Long-term anticonvulsant therapy in tuberculous meningitis - a four-year follow-up. J Trop Pediatr. 1996;42;98-103.

18. Marais S, Pepper DJ, Schutz C, Wilkinson RJ. Presentation and outcome of tuberculous meningitis in a high HIV prevalence setting. PLoS One. 2011;6(5):e20077.

19. Ikeda A, Klem GH, Lüders HO. Metabolic, infectious, and hereditary encephalopathies. Dalam: Ebersole JS, Pedley TA, Editors. Current practice of clinical electroencephalography. Edisi ke-3. Lippincott Williams \& Wilkins: Philadelphia. 2003. h. 349-78. 